- e ISSN-0976-6855 | Visit us : www.researchjournal.co.in

\title{
Insect pest complex of chilli, Capsicum annum L. and their natural enemies in Jabalpur
}

\author{
P.S. CHINTKUNTLAWAR ${ }^{1}$, U.A. PAWAR* AND A.K. SAXSENA ${ }^{2}$
}

Department of Agricultural Entomology, K.K. Wagh College of Agriculture, Panchavati, NASHIK (M.S.) INDIA ${ }^{1}$ Department of Plant Protection, Institute of Agricultural Sciences, Palli Siksha Bhavana, Visva Bharti, Bolpur, BIRBHUM (W.B.) INDIA

${ }^{2}$ Department of Agricultural Entomology, Jawaharlal Nehru Krishi Vishwa Vidyalaya, JABALPUR (M.P.) INDIA

\section{ARITCLE INFO}

Received : 28.04 .2015

Revised : 07.08 .2015

Accepted : 22.08.2015

KEY WORDS :

Chilli, Key pest, Predator, Parasitoid, Canopy level
*Corresponding author: Email: udaypawar91@gmail.com

\begin{abstract}
A field experiment was conducted at experimental field of the Department of Horticulture, Maharajpur, J.N. Krishi Vishwa Vidyalaya, Jabalpur (M.P.) during winter season of 2009-10. In chilli, six species of insect pests and two species of cocinellid predator and one braconid parasitoid of aphid were enumerated. At first sucking pests like whitefly, thrips, aphid and jassid were appeared at 7 days after transplanting and remained active till onset of reproductive stage. The Lepidopteron borers viz., Helicoverpa armigera and Spodoptera litura tobacco caterpillar and gram pod borer appeared were the next group of insects appear on the crop during reproductive stage and remained there till the crop matures. All these are the key pests of chilli in the region which caused colossal yield losses. The natural enemies observed were two species of lady bird beetle and a parasitoid of aphid. Parasitoid of aphid was observed when the crop was about 63 and 84 days old, respectively i.e. the reproductive stage it is evident that the natural enemies was present on the aphids when which remained active up to the third week of March i.e. aphids population were disappeared in the reproductive stage of the crop.
\end{abstract}

How to view point the article : Chintkuntlawar, P.S., Pawar, U.A. and Saxsena, A.K. (2015). Insect pest complex of chilli, Capsicum annum L. and their natural enemies in Jabalpur. Internat. J. Plant Protec., 8(2) : 270-278. 